\title{
The impact of tax gap on macroeconomic stability: Assessment using panel VEC approach
}

\author{
Oleksii Lyulyov \\ Department of Marketing, Sumy State University, \\ Ukraine \\ alex_lyulev@econ.sumdu.edu.ua \\ ORCID 0000-0002-4865-7306
}

\section{Serhiy Lyeonov}

Sumy State University,

Ukraine

s.lieonov@uabs.sumdu.edu.ua

ORCID 0000-0001-5639-3008

\author{
Inna Tiutiunyk \\ Department of Finance and Entrepreneurship, Sumy State University, \\ Ukraine \\ i.karpenko@finance.sumdu.edu.ua \\ ORCID 0000-0001-5883-2940

\section{Joanna Podgórska} \\ University of Information Technology and Management in Rzeszow, \\ Rzeszow, Poland \\ jpodgorska@wsiz.edu.pl \\ ORCID 0000-0002-6625-2767
}

Abstract. Imperfect tax legislation, high levels of corruption, and shadow economy lead to the deterioration of macroeconomic situation and economic imbalances in the countries. The state's actual tax revenues' inconsistency to its potential opportunities becomes the most acute problem for many countries. These processes cause a reduction in budget revenues due to the formation of tax gaps. The research aims to establish the causal links between tax gaps in the main types of taxes and the macroeconomic stability level. A comparative analysis of the theoretical basis for assessing the macroeconomic stability shows that to the 
authors have found that taxpayers often resort to various understatement schemes of their VAT and customs duties out of all indirect taxes. The volume of tax gaps for value added tax is calculated in the research. An empirical study on the causal relationships of tax gaps on value added tax and macroeconomic stability is carried out in the following logical sequence: determining the order of series integration using single root tests (ADF, IPS, LLC); evaluation of series cointegration by means of panel tests (Pedroni and Kao), determination of the strength and direction of the causal relationship between the series based on a dynamic approach (VEC model). The findings on the volume of tax gaps by major types of taxes and their causal links with the macroeconomic stability level may become targets for the organization's legal regulation over paying taxes to the state budget.

Keywords: national economy, pentagon of macroeconomic stability, stabilization policy, tax gap.

JEL Classification: E60, E63, C23

\section{INTRODUCTION}

Current trends in the national economy, which occur under the conditions of uncertainty and extreme variability, lead to a number of qualitative and quantitative factors that affect the level of macroeconomic stability in the country. Traditionally, financial, and economic parameters are considered to be the country's system-forming factors of macroeconomic stability and economic growth (Alheet \& Hamdan, 2020; Haller, 2020; Kalkabayeva et al., 2020; Sokolovska et al., 2020). The tax component is one of the essential elements for state budget revenues and a guarantee of its functions' performance. Understanding of the nature and significance of direct and indirect taxes by the world community has been transformed. Still, the mechanisms of tax collection have remained almost unchanged. Taxes, as the central budget-forming part of the economy, are seen as an effective tool to support priority sectors, types and areas of economic activity, assistance to vulnerable groups, increase in domestic enterprises' competitiveness, and improved economic development and macroeconomic stability.

Of all the indirect taxes, taxpayers often resort to various schemes to underestimate their VAT and customs duties. One of the reasons for the active use of VAT avoidance schemes is its calculation and payment (Zolkover \& Terziev, 2020c; Vasilyeva et al., 2016). The possibility of direct repayment defined in tax legislation, provided that the tax credit exceeds the amount of tax liability, part of the budget often encourages the use of various schemes to manipulate their values. Thus, any illegal actions taken by business entities (VAT payers) to evade this tax can be a real threat to achieving the country's stable economic development, the state performing its functions and ensuring macroeconomic stability.

In more economically developed countries the share of VAT can be up to $20 \%$ (Japan - 12\%, Canada - 14\%, etc.), in Ukraine its value exceeds $50 \%$ of the budget revenues (Fig. 1). Thus the role of VAT for filling the state budget is really a critical one. It is important to analyse the completeness and stability of its revenue because it largely depends on the timeliness of funding the expenditure side of the budget. 


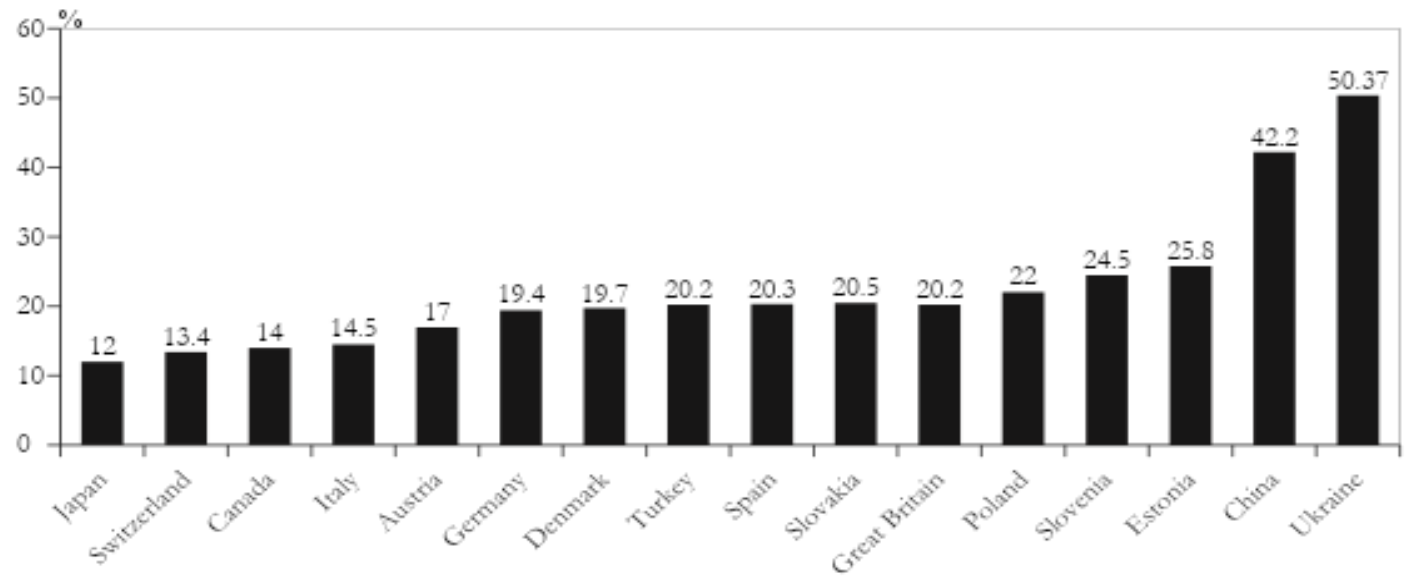

Figure 1. The shares of VAT in state budget revenues by countries

Source: Developed by the authors based on the World Bank data (2020)

Taking any illegal action to minimize VAT liability to a greater extent than other payments harm state's economic development and its macroeconomic stability (Boiko \& Samusevych, 2017; Zolkover \& Georgiev, 2020a). In this regard, it is essential to find, develop and implement appropriate mechanisms and algorithms for assessing the impact of tax gaps to timely coordinate and synchronize public policy to achieve macroeconomic stability in the context of globalization.

\section{LITERATURE REVIEW}

Murphy and Guter-Sandu (2018), the total tax gap in the EU for all taxes is 825 billion euros per year. At the same time, Harremi (2014) argues that $80-90 \%$ of the tax gap in any country is formed precisely due to tax evasion. Under these conditions, understanding the scale and structure of income losses could be the key to solving the problem of underpayment of tax liabilities and prevent their occurrence. In general, budget shortfalls in tax revenues could have various causes. Although these phenomena pose a severe problem to society because they limit the government's capacity to pursue its fiscal and economic policies, they also undermine basic tax principles. For the most part, the tax gap is viewed from two central positions (Dankiewicz \& Simionescu, 2020; Kuek et al., 2021): taxpayers' intentional illegal actions (tax compliance gap) and as a consequence of inefficient or fairly loyal tax policy gap. The latter is a potential amount of taxes and fees that do not go to the budget due to the government's decision not to tax a specific tax base. Also, it is the value of tax benefits, allowances and benefits provided by the government to compensate for a source of income that might otherwise be taxed.

VAT is one of the few indirect taxes, the specific feature of which is the possibility of a direct refund of part of the budget in the form of a tax credit if it exceeds tax liability. Given this feature of VAT, business entities - taxpayers have developed many schemes and mechanisms for intentional overstatement of tax credit amounts. The existence of a practical, fair and effective regulatory framework for the operation of VAT does not ensure the completeness and timeliness of its payment. Quite often, the presence of a wide range of benefits and special conditions for calculating this tax is used by taxpayers to obtain unjustified benefits. These features form the preconditions for strengthening control over the effectiveness of administering procedures for charging and paying VAT by tax authorities rather than its regulatory support.

Two methods of evaluating tax gaps are widely used (Vasylieva et al., 2013; Vasylieva et al., 2018; Levchenko et al., 2019; Svabova et al., 2020) in the world practice of assessing the effectiveness of VAT administration: macroeconomic (top-down) and microeconomic (bottom-up). The top-down method is a macroeconomic assessment of the difference between potential and actual tax revenues. The disadvantage 
of this approach is that it allows estimating only those activities and sectors of the economy that could be traced in macroeconomic statistics; the quality of the obtained results depends on the completeness and correctness of the original data, which are sufficiently aggregated and are not subject to detail; official macroeconomic statistics do not reflect the international aspects of tax evasion related to offshore withdrawals, investments abroad, etc.; the results obtained based on these approaches, as a rule, have a time lag of 2 years and require regular review. The advantage of this method is the absence of high costs of resources and time and the suitability of the results for comparison.

The bottom-up approach's difference is the high level of detail of calculations, which allows not only to determine the number of tax gaps by individual types of taxes, transactions and activities but also to obtain information on compliance with tax laws by each taxpayer. Simultaneously, this approach covers only specific sources of the tax gap and does not provide a comprehensive picture of the total tax gaps in the economy, does not provide an assessment of intentional and covert actions of economic entities aimed at reducing tax liabilities. The practice of assessing tax gaps is used in many countries, both high and medium level of development. The Belgian government has not developed an approach to estimating the VAT gap at the state level. The Ministry of Finance conducts an analysis based on the CASE survey results and evaluations conducted at the EU level by analysing the amount of budget and tax expenditures. However, the lack of its approach, adapted to the country's economic development realities, does not allow rational and practical use of these results in public policy.

The Czech Republic Government estimates the VAT gap on a top-down basis based on the Ministry of Finance. Valuations are carried out on a consolidated basis for all taxpayers and are not used within individual sectors of the economy or economic entities. The calculation of the gap is carried out in four stages:

The theoretical basis of VAT taxation within the entire economy is estimated.

The effective VAT rate for the whole economy is determined.

The effective VAT rate is applied to the theoretical tax base, as a result of which the theoretically possible amount of VAT is defined.

The potential amount of VAT is compared with its actual revenues.

The difference between the number of theoretical liabilities and actual revenues is the VAT tax gap.

The VAT gap in Estonia is estimated on a top-down basis and covers about 75,000 registered VAT payers. The valuation methodology is based on national accounts data and is similar in methods to the CASE survey approach. The accumulated financial statements are used to calculate the actual amount of VAT, i.e. the VAT paid refers to the period in which the liability arose. When estimating the VAT gap in the current year, the target year's potential liability is compared with the amount of tax paid in the same year.

A top-down approach is used in France to determine the VAT gap, and data are prepared by the French National Institute of Statistics and Economic Research (INSEE) with the French Treasury's support. The VAT gap is estimated for the whole economy and is not subject to sectoral breakdown. Theoretically, the tax gap is calculated using national accounts data, VAT refund data (at the aggregate level) and specific sales statistics for some goods (e.g., agriculture, water and energy).

The Tax Administration in Latvia started estimating the VAT gap in 2014 and is still applying it. Calculations are prepared using a top-down methodology that uses national accounts data and some additional data sources to estimate the potential amount of VAT. Potential VAT is compared with the amount of tax paid by taxpayers. In Lithuania, the tax administration has recently started counting the VAT gap. Calculations are performed on their own and are based on different approaches. Both the top-down method and the bottom-up process are used to estimate the VAT gap. Also, gaps are also assessed through surveys. The top-down methodology covers the entire set of taxpayers, and the bottom-up method covers 
approximately $62 \%$ of taxpayers. In the latter case, the tax liabilities of unregistered taxpayers, whose declared annual sales are less than 300 euros and persons registered as VAT payers for a period of fewer than 1.5 years, are not considered in the assessment.

The Ministry of Finance of Poland has only recently begun estimating the volume of shadow financial flows based on the VAT gap. The evaluation is applied for the period from 2005 to 2014 and is carried out based on the method from top to bottom. The VAT gap is calculated as the difference between the theoretical VAT liability and the actual revenue with some adjustments; when estimating the final VAT base, each element (private consumption, public investment, intermediate government consumption, investment, and intermediate consumption of other sectors) is adjusted according to size the tax rate applicable to each of them in the relevant year.

In Portugal, the Tax Administration has begun to apply the RA-GAP methodology in cooperation with the IMF. Sectors of the economy can detail the results of the RA-GAP procedure. In Slovakia, the VAT gap is estimated using two different methods. In 2013, Slovakia joined the IMF's RA-GAP Program, and with the support of the IMF, it assessed the VAT gap for the period 2008-2012. In addition to this method of estimating the gap is carried out based on the method from top to bottom.

When determining the tax gap's size based on the RA-GAP method developed by the IMF, an approach similar to that used by individual taxpayers to decide on their personal liabilities is used. The amount of tax liability for each sector of the economy is defined as the amount of VAT paid on goods imported into the country's customs territory, plus VAT accrued on products sold on the domestic market, less VAT paid on export transactions. The VAT gap is defined as the difference between the total amount of VAT that should theoretically be paid under current tax law (i.e., including benefits and lower tax rates) and the amount of VAT collected over some time. This value can be expressed in absolute or percentage form.

Modern scientific research empirically confirms that social (Nelson, 2017; Kharazishvili et al., 2020; Hanić \& Jevtić, 2020), environmental (Lyulyov et al., 2019; Miskiewicz, 2018; Pimonenko et al., 2020), cultural (Zandi et al., 2020), political (Yelnikova \& Barhaq, 2020), institutional (Dkhili, 2018; Chygryn et al., 2018; Shkolnyk et al., 2020), financial Djalilov et al., 2015; Melnyk et al., 2018; Sanusi et al., 2017; Kuek et al., 2021), innovation and investment (Vasylieva \& Kasyanenko, 2013; Povolná \& Švarcová, 2017; Zakharkina et al., 2018; Pisár et al., 2020; Rutkauskas \& Stasytyte, 2020; Petroye et al., 2020), marketing (Harust \& Melnyk, 2019; Bondarenko et al., 2020; Shymon et al., 2020) factors in various combinations could both significantly strengthen and reduce the current level of macroeconomic stability of the national economy and its economic growth. Scholars also argue that the level of shadowing of the economy by increasing tax gaps affects the country's investment attractiveness, increases barriers to the country's entry into trade unions, promotes the outflow of labor and capital from the country, which directly affects the macroeconomic stability of the national economy (Kasztelnik, 2020; Nguyen \& Luong, 2020; OstrowskaDankiewicz \& Simionescu, 2020). In the context of the study of the tax channel of economic shadowing, Stankevičius \& Vasiliauskaite (2014) proved that the main catalysts of shadowing were the growth of the tax burden (to a greater extent labor taxation, to a lesser extent consumption taxes), regulatory pressure and social security burden. In a paper (Christopoulos, 2003) based on Greece's data for 1960-1997, it was shown that when indirect and direct taxes increase, taxpayers go into the shadows as quickly as they leave it when these taxes decrease. In the work of the former Minister of Economic of Brazil C. J. Costa et al. (2020), the interaction between fiscal shocks and shadowing and its macroeconomic consequences in developing countries has been explored through the influence of trade unions regulation of the minimum wage. The paper (Bolan et al., 2019) formalized the causal links between economic shadowing drivers and the demand level in the investment market. Dharmapala (2008) analyses the schemes and impact of foreign direct 
investment through offshore areas on the level of economic shadowing. Herkenrath M. (2014) concludes that tax gaps weaken social, political, macroeconomic stability in developing countries.

Despite the great attention of scientists to the problems of de-shadowing and its impact on the stabilization process in the economy, several theoretical and applied issues remain unresolved, including, in particular, determining the level of tax gaps, confirmation of causal links between VAT gaps and macroeconomic stability.

\section{METHODOLOGY}

Methods and approaches of system dynamics was used to empirically confirm the causal links between VAT tax gaps and macroeconomic stability. Seven European countries (Bulgaria, Ukraine, Latvia, Lithuania, Poland, Croatia, Romania) were selected as the study's object. These countries have two common characteristics: in the political sphere in 1990-1992, they began political transformations in the direction of abandoning the monopoly of power of the Communist Party; and in economic - the transition from centralized governance to a market economy. The study period is 2013-2018. The first determines the order of integration of series using unit root tests (Hadri (2000), Levin et al. (LLC) (2002), and Im et al. (IPS) (2003)). Provided that the variables are integrated of order one, the cointegration of the series would be further assessed by Pedroni's (2000) and Kao (1999) panel tests using the model:

$$
M S P_{i t}=a_{i}+\delta t+\beta T G_{i t}+\varepsilon_{i t}
$$

where $M S P$ and $T G$ - the natural logarithms of macroeconomic stability and the VAT tax gap, respectively, $a, \delta$ - country and time fixed effects, respectively, $\varepsilon$ - errors, $\mathrm{i}=1 \ldots \mathrm{N}$ represent countries observed over periods $\mathrm{t}=1 \ldots \mathrm{t}$.

Defining the strength and direction of the causal relationship between series, similar to work (Skare \& Cvek, 2020; Škare et al., 2020a; Škare et al M., 2020b), will be based on the dynamic approach of the VEC model:

$$
\begin{aligned}
& \Delta M S P_{i t}=\theta_{1 j}+\sum_{k=1}^{m} \theta_{11 i k} \Delta M S P_{i t-k}+\sum_{k=1}^{m} \theta_{12 i k} \Delta T G_{i t-k}+\tau_{1 i} E C T_{i t-1}+u_{1 i t} \\
& \Delta T G_{i t}=\theta_{2 j}+\sum_{k=1}^{m} \theta_{21 i k} \Delta T G_{i t-k}+\sum_{k=1}^{m} \theta_{22 i k} \Delta M S P_{i t-k}+\tau_{2 i} E C T_{i t-1}+u_{2 i t}
\end{aligned}
$$

where $\Delta$ - first differences, $\mathrm{k}$ - the optimal lag length determined by the Schwarz Bayesian Criterion, $\theta-$ regression's parameter which would be estimated; $E C T$ - indicates long-term effect; $\tau$ - a parameter which characterised the deviation of the variables from the long-term equilibrium.

Comparative analysis of the theoretical basis for assessing the level of macroeconomic stability of the national economy (Lyulyov \& Shvindina, 2017; Remeikienè et al., 2019; Kološta et al., 2019; Biegun \& Karwowski, 2020; Roszko-Wójtowicz \& Grzelak, 2020; Zolkover \& Renkas, 2020b ) testified that to the greatest extent the requirement to ensure the reliability of comparisons of different countries and achieve the main goals of the state stabilization policy is met using the concept of the pentagon of macroeconomic stability. As a kind of analysis of macroeconomic stability, the director of the Institute of Finance in Warsaw, Professor of Economics Kolodko G. W. (1993), proposed a model of the pentagon of macroeconomic stability "Macroeconomic stabilization Pentagon" (MSP). This model is designed to assess the level of economic development considering the internal and external imbalances. The model of the pentagon of macroeconomic stability is based on the calculation of five key indicators that reflect the five signs of macroeconomic stability: the level of GDP growth (r); unemployment rate (U); inflation rate (CPI); state budget balance to GDP $(\mathrm{G})$

$$
M S P=[(r \times U)+(U \times C P I)+(C P I \times G)+(G \times C A)+(C A \times r)] \times k
$$


where $\mathrm{k}=1 / 2 \sin 72^{\circ}$

Thus, the level of overall macroeconomic stability of the country is directly proportional to the surface area of the pentagon. In contrast, the degree of balance of the pentagon's shape indicates the level of coordination of individual vectors of regulatory policy. To ensure positive economic growth and economic stability, it is desirable to maintain the synthetic MSP indicator's value at the highest possible level. This approach was adopted in investigation as a basis for calculating the level of macroeconomic stability.

Given the analysis of approaches to defining the size of the tax gap (Androniceanu et al., 2019; Vasilyeva et al., 2019; Al Quraan, 2020; Mishchuk et al., 2020), estimating the amount of potential tax revenues value added is carried out according to the formula:

$$
\begin{aligned}
& \operatorname{VAT}_{\mathrm{u}}^{\mathrm{hyp}}=\sum_{\mathrm{i}=1}^{\mathrm{n}}\left(\mathrm{t}_{\mathrm{z}, \mathrm{u}} \mathrm{aC} \mathrm{C}_{\mathrm{i}, \mathrm{u}}+\mathrm{t}_{\mathrm{R}, \mathrm{u}} \beta \mathrm{C}_{\mathrm{i}, \mathrm{u}}+\mathrm{t}_{\mathrm{N}, \mathrm{u}} \gamma \mathrm{C}_{\mathrm{i}, \mathrm{u}}\right)+\sum_{\mathrm{i}=1}^{\mathrm{n}}\left(\mathrm{t}_{\mathrm{z}, \mathrm{u}} \mathrm{aK} \mathrm{K}_{\mathrm{i}, \mathrm{u}}^{\mathrm{g}}+\mathrm{t}_{\mathrm{R}, \mathrm{u}} \beta \mathrm{K}_{\mathrm{i}, \mathrm{u}}^{\mathrm{g}}+\mathrm{t}_{\mathrm{N}, \mathrm{u}} \gamma \mathrm{K}_{\mathrm{i}, \mathrm{u}}^{\mathrm{g}}\right)+ \\
& \sum_{\mathrm{j}=1}^{\mathrm{m}}\left(\mathrm{t}_{\mathrm{R}, \mathrm{u}} \delta \mathrm{I}_{\mathrm{j}, \mathrm{u}}^{\mathrm{g}}+\mathrm{t}_{\mathrm{N}, \mathrm{u}} \varphi \mathrm{I}_{\mathrm{j}, \mathrm{u}}^{\mathrm{g}}\right)+\sum_{\mathrm{i}=1}^{\mathrm{n}}\left(\mathrm{t}_{\mathrm{z}, \mathrm{u}} \mathrm{a} \mathrm{K}_{\mathrm{i}, \mathrm{u}}^{\mathrm{o}}+\mathrm{t}_{\mathrm{R}, \mathrm{u}} \beta \mathrm{K}_{\mathrm{i}, \mathrm{u}}^{\mathrm{o}}+\mathrm{t}_{\mathrm{N}, \mathrm{u}} \gamma \mathrm{K}_{\mathrm{i}, \mathrm{u}}^{\mathrm{g}}\right)+\sum_{\mathrm{j}=1}^{\mathrm{m}}\left(\mathrm{t}_{\mathrm{R}, \mathrm{u}} \delta \mathrm{I}_{\mathrm{j}, \mathrm{u}}^{\mathrm{o}}+\mathrm{t}_{\mathrm{N}, \mathrm{u}} \varphi \mathrm{I}_{\mathrm{j}, \mathrm{u}}^{\mathrm{o}}\right)+ \\
& \sum_{\mathrm{i}=1}^{\mathrm{n}}\left(\mathrm{t}_{\mathrm{z}, \mathrm{u}} \mathrm{a} \mathrm{K}_{\mathrm{i}, \mathrm{u}}^{\mathrm{f}}+\mathrm{t}_{\mathrm{R}, \mathrm{u}} \beta \mathrm{K}_{\mathrm{i}, \mathrm{u}}^{\mathrm{f}}+\mathrm{t}_{\mathrm{N}, \mathrm{u}} \gamma \mathrm{K}_{\mathrm{i}, \mathrm{u}}^{\mathrm{f}}\right)+\sum_{\mathrm{j}=1}^{\mathrm{m}}\left(\mathrm{t}_{\mathrm{R}, \mathrm{u}} \delta \mathrm{I}_{\mathrm{j}, \mathrm{u}}^{\mathrm{f}}+\mathrm{t}_{\mathrm{N}, \mathrm{u}} \varphi \mathrm{I}_{\mathrm{j}, \mathrm{u}}^{\mathrm{f}}\right)+\sum_{\mathrm{i}=1}^{\mathrm{n}}\left(\mathrm{t}_{\mathrm{z}, \mathrm{u}} \mathrm{a} \mathrm{K}_{\mathrm{i}, \mathrm{u}}^{\mathrm{h}}+\mathrm{t}_{\mathrm{R}, \mathrm{u}} \beta \mathrm{K}_{\mathrm{i}, \mathrm{u}}^{\mathrm{h}}+\right. \\
& \left.\mathrm{t}_{\mathrm{N}, \mathrm{u}} \gamma \mathrm{K}_{\mathrm{i}, \mathrm{u}}^{\mathrm{h}}\right)+\sum_{\mathrm{j}=1}^{\mathrm{m}}\left(\mathrm{t}_{\mathrm{R}, \mathrm{u}} \delta \mathrm{I}_{\mathrm{j}, \mathrm{u}}^{\mathrm{h}}+\mathrm{t}_{\mathrm{N}, \mathrm{u}} \varphi \mathrm{I}_{\mathrm{j}, \mathrm{u}}^{\mathrm{h}}\right)+\sum_{\mathrm{i}=1}^{\mathrm{n}}\left(\mathrm{t}_{\mathrm{z}, \mathrm{u}} \mathrm{a} \mathrm{K}_{\mathrm{i}, \mathrm{u}}^{\mathrm{l}}+\mathrm{t}_{\mathrm{R}, \mathrm{u}} \beta \mathrm{K}_{\mathrm{i}, \mathrm{u}}^{\mathrm{l}}+\mathrm{t}_{\mathrm{N}, \mathrm{u}} \gamma \mathrm{K}_{\mathrm{i}, \mathrm{u}}^{\mathrm{l}}\right)+\sum_{\mathrm{j}=1}^{\mathrm{m}}\left(\mathrm{t}_{\mathrm{R}, \mathrm{u}} \delta \mathrm{I}_{\mathrm{j}, \mathrm{u}}^{\mathrm{l}}+\right. \\
& \left.\mathrm{t}_{\mathrm{N}, \mathrm{u}} \varphi \mathrm{I}_{\mathrm{j}, \mathrm{u}}^{\mathrm{l}}\right)+\sum_{\mathrm{i}=1}^{\mathrm{n}}\left(\mathrm{t}_{\mathrm{z}, \mathrm{u}} \mathrm{a} \mathrm{K}_{\mathrm{i}, \mathrm{u}}^{\mathrm{p}}+\mathrm{t}_{\mathrm{R}, \mathrm{u}} \beta \mathrm{K}_{\mathrm{i}, \mathrm{u}}^{\mathrm{p}}+\mathrm{t}_{\mathrm{N}, \mathrm{u}} \gamma \mathrm{K}_{\mathrm{i}, \mathrm{u}}^{\mathrm{p}}\right)+\sum_{\mathrm{j}=1}^{\mathrm{m}}\left(\mathrm{t}_{\mathrm{R}, \mathrm{u}} \delta \mathrm{I}_{\mathrm{j}, \mathrm{u}}^{\mathrm{p}}+\mathrm{t}_{\mathrm{N}, \mathrm{u}} \varphi \mathrm{I}_{\mathrm{j}, \mathrm{u}}^{\mathrm{p}}\right),
\end{aligned}
$$

where: $\mathrm{tZ}, \mathrm{tR}, \mathrm{tN}$ - zero, reduced and standard VAT rate; $\mathrm{u}$ - tax period; $\mathrm{i}$ - consumer product or service $(i=1,2, \ldots, n) ; j-$ investment goods $(j=1,2, \ldots, m) ; \alpha, \beta, \gamma-$ the share of consumer goods and services that are taxed at different rates $(\alpha+\beta+\gamma=1) ; \delta, \varphi$ - the share of investment goods that are taxed at different rates $(\delta+\varphi=1)$; C - final consumption by private households; $\mathrm{Kg}$ - intermediate consumption by state and local authorities; Ig - the investment from state and local authorities; Ko - the investment from state and local authorities; Io - investment from non-profit private institutions; $\mathrm{Kf}$ - intermediate consumption by banks and insurance companies; If - the investments from banks and insurance companies; Kh intermediate consumption in the health sector; $\mathrm{Ih}$ - the investment in the health sector; $\mathrm{Kl}$ - intermediate consumption in the real estate market (in the rental sector of houses and apartments); 1 -investments in the rental sector of houses and apartments; $\mathrm{Kp}$ - intermediate consumption by public or non-profit private institutions (postal service, lotteries, etc.); Ip - investment made from public or non-profit private institutions.

In contrast to the existing ones, this approach considers the differentiation of tax rates for each type of entities and operations, which allows to assess their volumes due to the shadowing of the national economy and to identify tools for managing VAT tax gaps, economy and increase the level of its macroeconomic stability.

The descriptive statistics of macroeconomic stability and the VAT tax gap are presented in Table 1.

The analysis of the data in Table 1 showed different rates of change in the macroeconomic stability of the studied countries' national economies. Thus, Ukraine and Latvia in the period from 2013 to 2018 showed the lowest average level of the MSP indicator. It should be noted that the rate of decline of SMEs in Ukraine from 30.1 in 2013 to 16.1 in 2018 allows concluding that there is a lack of proper coordination of economic policy pursued by Ukraine to achieve a high level of macroeconomic stability of external factors. Croatia and Romania in the post-crisis period showed the best indicators of macroeconomic stabilization. At the same time, the Croatian economy in 2013 showed one of the lowest levels of overall macroeconomic stability of SMEs. After joining the EU, the value of macroeconomic stability proliferated and reached its maximum value in $2018-40.9 \%$. The volume of VAT tax gaps in Ukraine is one of the highest among the analysed countries and ranges from 39 to $42 \%$, while in most European Union countries, it does not exceed $25 \%$. 
Table 1

The exogenous and endogenous parameters of the model (3)

\begin{tabular}{|c|c|c|c|c|c|c|c|c|c|c|c|c|}
\hline & & Mean & Median & Max. & Min. & Std. Dev. & Skewn. & Kurtosis & Jarque-Bera & Prob. & Sum & $\begin{array}{c}\text { Sum Sq. } \\
\text { Dev. }\end{array}$ \\
\hline \multirow{2}{*}{$\begin{array}{c}\text { All } \\
\text { countries }\end{array}$} & MSP & 35.51 & 33.45 & 63.20 & 3.90 & 11.96 & 0.16 & 3.43 & 0.52 & 0.77 & 1491.50 & 5862.74 \\
\hline & TG & 27.38 & 25.33 & 42.63 & 19.81 & 7.12 & 0.92 & 2.51 & 6.30 & 0.04 & 1149.94 & 2075.78 \\
\hline \multirow{2}{*}{ Ukraine } & MSP & 24.32 & 24.90 & 32.90 & 16.10 & 6.79 & -0.08 & 1.58 & 0.51 & 0.77 & 145.90 & 230.47 \\
\hline & TG & 41.09 & 41.24 & 42.63 & 39.77 & 1.06 & 0.08 & 1.92 & 0.30 & 0.86 & 246.51 & 5.58 \\
\hline \multirow{2}{*}{ Latvia } & MSP & 24.08 & 26.55 & 33.50 & 3.90 & 10.84 & -1.17 & 3.09 & 1.37 & 0.51 & 144.50 & 587.75 \\
\hline & TG & 21.10 & 21.16 & 22.17 & 19.81 & 0.85 & -0.30 & 1.99 & 0.34 & 0.84 & 126.62 & 3.59 \\
\hline \multirow{2}{*}{ Lithuania } & MSP & 43.40 & 39.85 & 63.20 & 31.20 & 12.13 & 0.67 & 2.09 & 0.66 & 0.72 & 260.40 & 736.22 \\
\hline & TG & 21.47 & 21.57 & 22.71 & 20.01 & 0.99 & -0.24 & 1.84 & 0.40 & 0.82 & 128.81 & 4.92 \\
\hline \multirow{2}{*}{ Poland } & MSP & 41.72 & 38.50 & 55.70 & 33.40 & 8.49 & 0.78 & 2.13 & 0.79 & 0.67 & 250.30 & 360.61 \\
\hline & TG & 26.86 & 26.84 & 28.41 & 24.89 & 1.32 & -0.22 & 1.91 & 0.35 & 0.84 & 161.16 & 8.69 \\
\hline \multirow{2}{*}{ Bulgaria } & MSP & 41.75 & 41.65 & 52.90 & 32.20 & 7.50 & 0.21 & 1.92 & 0.33 & 0.85 & 250.50 & 281.58 \\
\hline & TG & 33.72 & 33.44 & 36.83 & 31.86 & 1.75 & 0.89 & 2.77 & 0.81 & 0.67 & 202.30 & 15.32 \\
\hline \multirow{2}{*}{ Romania } & MSP & 41.93 & 35.85 & 58.20 & 32.00 & 12.54 & 0.58 & 1.47 & 0.92 & 0.63 & 251.60 & 786.75 \\
\hline & TG & 25.65 & 25.78 & 27.51 & 23.91 & 1.39 & -0.04 & 1.71 & 0.42 & 0.81 & 153.89 & 9.62 \\
\hline \multirow{2}{*}{ Croatia } & MSP & 31.38 & 29.75 & 40.90 & 26.50 & 5.59 & 0.83 & 2.34 & 0.80 & 0.67 & 188.30 & 156.21 \\
\hline & TG & 21.78 & 21.78 & 23.22 & 20.22 & 1.10 & -0.10 & 1.79 & 0.38 & 0.83 & 130.65 & 6.02 \\
\hline
\end{tabular}

Source: Authors' calculations

\section{EMPIRICAL RESULTS AND DISCUSSION}

The results of checking the time series of macroeconomic stability and the tax gap for VAT on stationarity are presented in Table 2 .

Table 2

Panel unit root results for MSP, TG

\begin{tabular}{|c|c|c|c|c|}
\hline \multirow{3}{*}{ Variables } & \multicolumn{2}{|c|}{ Test statistics } & \multicolumn{2}{c|}{ Individual intercept } \\
\cline { 3 - 4 } & \multirow{3}{*}{ LLC } & Statistic & 1.3706 & First difference \\
\cline { 2 - 4 } & \multirow{2}{*}{ MSP } & p-value & 0.9147 & -3.465 \\
\cline { 2 - 4 } & \multirow{2}{*}{ IPS } & Statistic & 2.7428 & $0.000^{*}$ \\
\cline { 2 - 4 } & \multirow{2}{*}{ Hadri } & p-value & 0.9970 & -7.63 \\
\cline { 2 - 4 } & \multirow{2}{*}{ LLC } & Statistic & 0.4833 & $0.000^{*}$ \\
\cline { 2 - 4 } & & p-value & 0.3144 & 16.67 \\
\cline { 2 - 4 } & \multirow{2}{*}{ TSG } & Statistic & -21.728 & $0.000^{*}$ \\
\cline { 2 - 4 } & & p-value & $0.000^{*}$ & -18.869 \\
\cline { 2 - 4 } & & Statistic & 0.0723 & 0.000 \\
\cline { 2 - 4 } & \multirow{2}{*}{ Hadri } & p-value & 0.5288 & -4.32 \\
\cline { 2 - 4 } & & Statistic & 0.9605 & $0.000^{*}$ \\
\cline { 2 - 4 } & & p-value & 0.1684 & 14.18 \\
\hline
\end{tabular}

Source: Authors' calculations. ${ }^{*}$ represent significance at the $1 \%$ level

According to Table 2, the absolute value of the calculated value of McKinnon's $\tau$-statistics for the variables MSP and TG is less than the fundamental values of the critical value at $1 \%, 5 \%$ and $10 \%$ levels of significance. Therefore, it is impossible to reject the null hypothesis about the presence of a unit root in the time series, because the minimum probability that the series has a single source and is not stationary is more than $50 \%$ (p-value $>10 \%$ ). Thus, the null hypothesis of the existence of a single root is not rejected. It means that the series of variables MSP and TG in the levels are non-stationary. The operation of the first differences converts the series into stationary (Table 2). 
Since all series are nonstationary of the same order, there may be a cointegration relationship between them. Checking the time series MSP, TG for the presence of cointegration is presented in table 3.

Table 3.

Pedroni panel cointegration tests

\begin{tabular}{|c|c|c|c|c|c|}
\hline \multicolumn{2}{|c|}{ Within dimesion (panel statistics) } & \multicolumn{2}{c|}{ Between-dimension } \\
\hline Test & Statistic & Prob. & Test & Statistic & Prob. \\
\hline Panel v-Statistic & -1.94169 & 0.9739 & Group rho-Statistic & -1.98411 & 1.732173 \\
\hline Panel rho-Statistic & -1.24755 & 0.1061 & Group PP-Statistic & -1.44474 & $(0.0023)^{*}$ \\
\hline Panel PP-Statistic & -2.01383 & $(0.022)^{*}$ & Group ADF-Statistic & -2.23081 & -1.0826 \\
\hline Panel ADF-Statistic & -1.57703 & $(0.0574)^{* * *}$ & & \\
\cline { 1 - 2 } (weighted statistic) \\
\cline { 1 - 2 } Panel v-Statistic & -1.98411 & 0.9764 & & \\
\cline { 1 - 2 } Panel rho-Statistic & -1.44474 & $(0.0743)^{* * *}$ & & \\
\cline { 1 - 2 } Panel PP-Statistic & -2.23081 & $(0.0128)^{* *}$ & & \\
\cline { 1 - 2 } Panel ADF-Statistic & -1.66602 & $(0.0479)^{* *}$ & & \\
\end{tabular}

Source: Authors' calculations. *, **, *** indicate the rejection of the null hypothesis at $1 \%, 5 \%$ and $10 \%$

The results of using the Pedroni test, according to which the null hypothesis is that the variables are not cointegrated, indicate cointegration between the variables MSP, TG. Thus, at 1\%, 5\% and 10\% significant level, six models reject the null of no cointegration: within dimension (panel statistics) - Panel PP-Statistic (-2.01383), Panel ADF-Statistic (-1.57703); weighted statistic - Panel rho-Statistic (-1.44474), Panel PP-Statistic (-2.23081); ADF-Statistic Panel (-1.66602); between-dimension - Group PP-Statistic (1.44474).

Table 4 presents the results of the Kao Residual Cointegration Test.

Table 4

Kao Residual Cointegration Test

\begin{tabular}{|c|c|c|}
\hline \multicolumn{3}{|c|}{ Trend assumption: No deterministic trend } \\
\hline \multicolumn{1}{|c|}{ t-Statistic } & $(0.0141)^{* *}$ \\
\hline ADF & -2.1938 & \\
\hline Residual variance & 0.002086 & \\
\hline HAC variance & 0.001848 & \\
\hline
\end{tabular}

Source: Authors' calculations. represent significance at the $5 \%$ level

The findings in table 4 allowed rejecting the null hypothesis of lack of cointegration at the level of 5\% significance. It indicates a long relationship between MSP and TG for Bulgaria, Ukraine, Latvia, Lithuania, Poland, Croatia and Romania.

The estimation of VECM model parameters is shown in table 5.

Table 5

Panel vector error correction estimate

\begin{tabular}{|c|c|c|}
\hline Error Correction: & $\Delta(\mathrm{MSP})$ & $\Delta(\mathrm{TG})$ \\
\hline \multirow{2}{*}{$E C T_{t-1}$} & -0.2699 & -0.01569 \\
\cline { 2 - 3 } & {$[-4.43785]$} & {$[-1.05623]$} \\
\hline \multirow{2}{*}{$\Delta(\mathrm{MSP}(-1))$} & -0.34546 & 0.012006 \\
\cline { 2 - 3 } & {$[-3.48591]$} & {$[0.09597]$} \\
\cline { 2 - 3 }$\Delta(\mathrm{TG}(-1))$ & 1.064369 & 0.003264 \\
\cline { 2 - 3 } & {$[1.07865]$} & $0.01354]$ \\
\hline \multirow{2}{*}{$\mathrm{C}$} & 0.181927 & {$[1.92607]$} \\
\cline { 2 - 3 } & {$[3.74976]$} & 0.729638 \\
\hline R-squared & 0.827751 & 0.66048 \\
\hline Adj. R-squared & 0.770335 & \\
\hline
\end{tabular}

Source: Authors' calculations. t-statistics are provided in square brackets 
According to VECM modelling results, the ECT coefficients for equations (2) and (3) are negative and statistically significant at level 5 at 10\% and 5\%, respectively. The ECT also shows a relatively slow rate of convergence of the system to long-term equilibrium, due to the action of exogenous shocks, both for MSP $(-0.2699)$. The coefficient of determination (R-squared) for equation (2) is 0.827751 . It indicates that the interpretation is consistent.

The study of short-term relationships between variables MSP and TG based on the Granger test is shown in table 6.

VEC Granger Causality

Table 6

\begin{tabular}{|c|c|c|c|c|}
\hline \multirow{2}{*}{ Dependent variables } & \multicolumn{2}{|c|}{ Short run } & Long run & \multirow{2}{*}{ Conclusion } \\
\cline { 2 - 4 } & $\Delta$ (MSP) & $\Delta(\mathrm{TG})$ & ECMt_1 & \\
\hline \multirow{2}{*}{$\Delta(\mathrm{MSP})$} & - & -5.642847 & -0.2699 & \multirow{2}{*}{ MSP $>$ TG } \\
\hline \multirow{2}{*}{$\Delta(\mathrm{TG})$} & -0.278367 & - & $-0.0595)^{* * *}$ & {$[-01569$} \\
& $(0.0701)^{* * *}$ & - & \multirow{2}{*}{ TG $\neq>$ MSP } \\
\hline
\end{tabular}

Source: Authors' calculations. ${ }^{* * *}$ represent significance at the $10 \%$ level; t-statistics are provided in square brackets

The data in Table 6 indicate the existence of unidirectional causality of Granger at 10\% of statistical significance. That is, increasing macroeconomic stability could reduce the tax gap, and conversely, reducing the tax gap could increase macroeconomic stability.

\section{CONCLUSION}

The study examines the causal links between macroeconomic stability and the tax gap for seven European countries (Bulgaria, Ukraine, Latvia, Lithuania, Poland, Croatia and Romania) using econometric analysis in the period 2013-2018. The cointegration results in both tests indicate a long-term relationship between macroeconomic stability and the level of the tax gap. According to the Panel Vector Error Correction Estimate, there is a bidirectional causal relationship between macroeconomic stability and the tax gap and a negative bilateral causal relationship in the short run. Thus, the study results confirmed the hypothesis that in countries with a higher level of macroeconomic stability, the tax gaps is smaller. These results are consistent with the previously findings (Bilan et al., 2019,2020).

Thus, anti-corruption public policies and tax reforms contribute to regulatory influence in the fight against national shadowing, thus increasing macroeconomic stability. At the same time, the reduction of tax gaps resulted from consolidating macroeconomic stability and restoring economic growth of the studied countries, improving the business climate in the context of business deregulation policy, which, in turn, helped increase investor confidence and increase direct investment.

The findings of the investigation are of practical value, on the one hand, for government agencies involved in the development and implementation of state policy to ensure macroeconomic stability, and on the other - for government officials who form the basic principles of state policy to combat economic shadowing. Thus, the confirmation of the hypotheses proposed in the paper on the relationship between the factor of influence (VAT tax gaps) and the result (the level of macroeconomic stability) allowed identifying the vector and nature of such relationships.

In the context of implementing the state policy of increasing the level of macroeconomic stability in the national economy, the most relevant tools for managing VAT tax gaps are improving the procedure of electronic VAT administration (preventing excessive tax credit and illegal budget reimbursement), revising the list of tax benefits business transactions and risk analysis. Using the method of assessing tax gaps allowed avoiding the shortcomings of traditional approaches, assess the administration process's effectiveness in 
terms of certain types of taxes, identify the most problematic points of their legislation, and assess the level of shadowing of certain sectors and industries.

\section{ACKNOWLEDGEMENT}

This research was funded by the grant "Quadrocentric recursive model of de-shadowing of Ukraine's economy for growth of its macroeconomic stability" (0120U104798, funding - National Research Foundation, 2020-2021).

\section{REFERENCES}

Al Quraan, A. R. (2020). General sales tax and economic growth in small open developing countries: Evidence from jordan. Montenegrin Journal of Economics, 16(3), 7-15. doi:10.14254/1800-5845/2020.16-3.1

Androniceanu, A., Gherghina, R., \& Ciobănașu, M. (2019). The interdependence between fiscal public policies and tax evasion. Administratie Si Management Public, 2019(32), 32-41. doi:10.24818/amp/2019.32-03

Biegun, K., \& Karwowski, J. (2020). Macroeconomic imbalance procedure (MIP) scoreboard indicators and their predictive strength of?multidimensional crises?. Equilibrium. Quarterly Journal of Economics and Economic Policy, 15(1), 11-28. https://doi.org/10.24136/eq.2020.001

Bilan, Y., Tiutiunyk, I., Lyeonov, S., \& Vasylieva, T. (2020). Shadow economy and economic development: A panel cointegration and causality analysis. International Journal of Economic Policy in Emerging Economies, 13(2), 173-193. doi:10.1504/IJEPEE.2020.107929

Bilan, Y., Vasylieva, T., Lyeonov, S., \& Tiutiunyk, I. (2019). Shadow economy and its impact on demand at the investment market of the country. Entrepreneurial Business and Economics Review, 7(2), 27-43. doi:10.15678/EBER.2019.070202

Boiko, A., Samusevych, I. (2017). The role of tax competition between the countries of the world and the features of determining the main tax competitors of Ukraine among the European countries. Financial Markets, Institutions and Risks, 1(1), 72-79. http://doi.org/10.21272/fmir.1(1).72-79.2017

Bondarenko, A. F., Zakharkina, L. S., Syhyda, L. O., \& Saher, L. Y. (2020). The economic and marketing attractiveness of countries: Measurement and positioning in terms of economic security. International Journal of Sustainable Development and Planning, 15(4), 439-449. doi:10.18280/ijsdp.150404

Christopoulos, D. K. (2003). Does underground economy respond symmetrically to tax changes? Evidence from Greece. Economic Modelling, 20(3), 563-570.

Chygryn, O., Petrushenko, Y., Vysochyna, A., \& Vorontsova, A. (2018). Assessment of fiscal decentralization influence on social and economic development. Montenegrin Journal of Economics, 14(4), 69-84. doi:10.14254/1800$5845 / 2018.14-4.5$

Dankiewicz, R., \& Simionescu, M. (2020). The insurance market in romania: A macroeconomic and a microeconomic approach. [Draudimo rinka Rumunijoje: Makroekonominis ir mikroekonominis metodai] Transformations in Business and Economics, 19(1), 248-261

Dharmapala, D. (2008). What problems and opportunities are created by tax havens?. Oxford Review of Economic Policy, 24(4), 661-679.

Djalilov, K., Lyeonov, S., \& Buriak, A. (2015). Comparative studies of risk, concentration and efficiency in transition economies. Risk Governance and Control: Financial Markets and Institutions, 5(4CONT1), 178-187. doi:10.22495/rgcv5i4c1art7

Dkhili, H. (2018). Environmental performance and institutions quality: evidence from developed and developing countries. Marketing and Management of Innovations, (3), 333-344. http://doi.org/10.21272/mmi.2018.3-30

Hadri, K. (2000). Testing for stationarity in heterogeneous panel data. The Econometrics Journal, 3(2), 148-161.

Haller, A. (2020). From classical and neoclassical economic growth to degrowth in europe. Challenges for public administration. Administratie Si Management Public, 2020(34), 150-170. doi:10.24818/amp/2020.34-9 
Hanić, A., \& Jevtić, D. (2020). Human resource management between economy and ethics - research of Serbia and Bosnia and Hercegovina. Business Ethics and Leadership, 4(3), 127-136. https://doi.org/10.21272/bel.4(3).127136.2020

Harremi, M. (2014). A simple analysis of the tax gap Balkan region. Mediterranean Journal of Social Sciences, $5(19), 365$.

Harust, Yu., \& Melnyk, V. (2019). Economic security of the country: marketing, institutional and political determinants. Marketing and Management of Innovations, 4, 373-382. http://doi.org/10.21272/mmi.2019.4-29

Herkenrath, M. (2014). Tax Havens and Capital Flight from Developing Countries: The Social and Political Implications. Revue d'economie du developpement, 22(HS02), 131-136.

Im, K. S., Pesaran, M. H., \& Shin, Y. (2003). Testing for unit roots in heterogeneous panels. Journal of econometrics, 115(1), 53-74.

Junior, C. J. C., Garcia-Cintado, A. C., \& Usabiaga, C. (n.d.). Fiscal adjustments and the shadow economy in an emerging market. Macroeconomic Dynamics, 1-35.

Kao, C. (1999). Spurious regression and residual-based tests for cointegration in panel data. Journal of Econometrics, 90(1), 1-44. doi:10.1016/S0304-4076(98)00023-2

Kasztelnik, K. (2020). Causal-Comparative macroeconomic behavioral study: international corporate financial transfer pricing in the United States. Financial Markets, Institutions and Risks, 4(1), 60-75. http://doi.org/10.21272/fmir.4(1).60-75.2020.

Kharazishvili, Y., Kwilinski, A., Grishnova, O., \& Dzwigol, H. (2020). Social safety of society for developing countries to meet sustainable development standards: indicators, level, strategic benchmarks (with calculations based on the case study of Ukraine). Sustainability, 12(21), 8953. https://doi.org/10.3390/su12218953

Kolodko, G. W. (1993). Stabilization, recession and growth in a postsocialist economy. MOST: Most: Economic Journal on Eastern Europe and the Soviet Union, 3(1), 3-38.

Kološta, S., Král', P., \& Flaška, F. (2019). Alternative measures of macroeconomic imbalances in the EU - design and verification. E a M: Ekonomie a Management, 22(1), 36-53. doi:10.15240/tul/001/2019-1-003

Kuek, T.-H., Puah, C.-H., Arip, M. A., \& Habibullah, M. S. (2021). Macroeconomic perspective on constructing financial vulnerability indicator in China. Journal of Business Economics and Management, 22(1), 181-196. https://doi.org/10.3846/jbem.2020.13220

Levchenko, V., Boyko, A., Bozhenko, V., \& Mynenko, S. (2019). Money laundering risk in developing and transitive economies: Analysis of cyclic component of time series. Business: Theory and Practice, 20, 492-508. doi:10.3846/btp.2019.46

Levin, A., Lin, C. F., \& Chu, C. S. J. (2002). Unit root tests in panel data: asymptotic and finite-sample properties. Journal of econometrics, 108(1), 1-24.

Lyulyov, O., Pimonenko, T., Stoyanets, N., \& Letunovska, N. (2019). Sustainable development of agricultural sector: Democratic profile impact among developing countries. Research in World Economy, 10(4), 97-105. doi:10.5430/rwe.v10n4p9

Lyulyuv, O., \& Shvindina, H. (2017). Stabilization pentagon model: application in the management at macro- and micro- levels. Problems and Perspectives in Management, 15(3), 42-52.

Melnyk, L., Sineviciene, L., Lyulyov, O., Pimonenko, T., \& Dehtyarova, I. (2018). Fiscal decentralization and macroeconomic stability: The experience of ukraine's economy. Problems and Perspectives in Management, 16(1), 105-114. doi:10.21511/ppm.16(1).2018.1

Mishchuk, H., Bilan, S., Yurchyk, H., Akimova, L., \& Navickas, M. (2020). Impact of the shadow economy on social safety: The experience of Ukraine. Economics and Sociology, 13(2), 289-303. doi:10.14254/2071-789X.2020/13$2 / 19$

Miskiewicz, R. (2018). The importance of knowledge transfer on the energy market. Polityka Energetyczna, 21(2), 49-62. http:/ /dx.doi.org/10.24425\%2F122774

Murphy, R., \& Guter-Sandu, A. (2018). Resources allocated to tackling the tax gap: a comparative EU study. Working paper for Combating Financial Fraud and Empowering Regulators (COFFERS) Horizon 2020 project, (A).

Nelson, E. M. (2017). Socioeconomic challenges - a global perspective evaluating invisible connections-resolutioning necessary global collaborative. SocioEconomic Challenges, 1(3), 116-119. doi:10.21272/sec.1(3).116-119.2017 
Nguyen, T. A. N., \& Luong, T. T. H. (2020). Corruption, shadow economy and economic growth: Evidence from emerging and developing asian economies. Montenegrin Journal of Economics, 16(4), 85-94. doi:10.14254/18005845/2020.16-4.7

Ostrowska-Dankiewicz, A., \& Simionescu, M. (2020). Relationship between the insurance market and macroeconomic indicators in the EU member states. [Draudimo rinkos ir makroekonominių rodiklių ryšys es valstybèse narèse] Transformations in Business and Economics, 19(3), 175-187.

Petroye, O., Lyulyov, O., Lytvynchuk, I., Paida, Y., \& Pakhomov, V. (2020). Effects of information security and innovations on Country's image: Governance aspect. International Journal of Safety and Security Engineering, 10(4), 459-466. doi:10.18280/ijsse.100404

Pimonenko, T., Us, Y., Lyulyova, L., \& Kotenko, N. (2021). The impact of the macroeconomic stability on the energyefficiency of the european countries: A bibliometric analysis. Paper presented at the E3S Web of Conferences, 234doi:10.1051/e3sconf/202123400013

Pisár, P., Durčeková, I., \& Stachová, M. (2020). The contribution of innovation actors into business r\&d funding does the substitution effect of public support work in the EU?. E a M: Ekonomie a Management, 23(1), 121-134. doi:10.15240/tul/001/2020-1-009

Povolná L., \& Švarcová J. (2017). The Macroeconomic context of investments in the field of machine tools in the Czech Republic. Journal of Competitiveness, 9(2), 110-122 https://doi.org/10.7441/joc.2017.02.08

Remeikienè, R., Gasparènienè, L., \& Sadeckas, A. (2019). The determinants of the competitiveness of Lithuanian export: macroeconomic approach. Business: Theory and Practice, 20, 170-178. https://doi.org/10.3846/btp.2019.16

Roszko-Wójtowicz, E., \& Grzelak, M. M. (2020). Macroeconomic stability and the level of competitiveness in EU member states: A comparative dynamic approach. Oeconomia Copernicana, 11(4), 657-688. doi:10.24136/OC.2020.027

Rutkauskas, A. V., \& Stasytyte, V. (2020). Stochastic informative expert system for investment. Journal of Business Economics and Management, 21(1), 136-156. https://doi.org/10.3846/jbem.2020.11768

Sanusi, K. A., Meyer, D., \& Ślusarczyk, B. (2017). The relationship between changes in inflation and financial development. [Związek między zmianami w inflacji a rozwojem finansowym]. Polish Journal of Management Studies, 16(2), 253-265. doi:10.17512/pjms.2017.16.2.22

Shkolnyk, I., Kozmenko, O., Nowacki, R., \& Mershchii, B. (2020). Dependence of the state of public finances on their transparency and the level of corruption in a country. Economics and Sociology, 13(4), 281-296. doi:10.14254/2071-789X.2020/13-4/18

Shymon, S., Kolomiets-Ludwig, E., Osiejewicz, Jo., Krawczyk, D., \& Kaminska, B. (2020). The Role of Country Brand in Providing Economic Resilience. Marketing and Management of Innovations, 1, 303-311. http://doi.org/10.21272/mmi.2020.1-26

Skare, M., \& Cvek, D. (2020). A vector autoregression analysis of foreign direct investment and its link to competitiveness. Journal of Competitiveness, 12(4), 127-142. https://doi.org/10.7441/joc.2020.04.08

Škare, M., Franc-Dąbrowska, J., \& Cvek, D. (2020a). Cointegration analysis and VECM of FDI, employment, export and GDP in Croatia (2002?2017) with particular reference to the global crisis and poor macroeconomic governance. Equilibrium. Quarterly Journal of Economics and Economic Policy, 15(4), 761-783. https://doi.org/10.24136/eq.2020.033

Škare, M., Radošević, D., \& Radolović, S. (2020b). Measuring the macroeconomic impact of economic diplomacy using varfima model for croatia 1990-2018. Economics and Sociology, 13(3), 230-243. doi:10.14254/2071789X.2020/13-3/14

Sokolovska, A., Zatonatska, T., Stavytskyy, A., Lyulyov, O., \& Giedraitis, V. (2020). The impact of globalization and international tax competition on tax policies. Research in World Economy, 11(4), 1-15. doi:10.5430/rwe.v11n4p1

Stankevičius, E., \& Vasiliauskaite, A. (2014). Tax burden level leverage on size of the shadow economy, cases of EU countries 2003-2013. Procedia-Social and Behavioral Sciences, 156, 548-552.

Svabova, L., Kramarova, K., Chutka, J., \& Strakova, L. (2020). Detecting earnings manipulation and fraudulent financial reporting in slovakia. Oeconomia Copernicana, 11(3), 485-508. doi:10.24136/OC.2020.020 
Vasilyeva, T., Kuzmenko, O., Bozhenko, V., \& Kolotilina, O. (2019). Assessment of the dynamics of bifurcation transformations in the economy. Paperpresented at the CEUR Workshop Proceedings, 2422 134-146.

Vasilyeva, T., Sysoyeva, L., \& Vysochyna, A. (2016). Formalization of factors that are affecting stability of ukraine banking system. Risk Governance and Control: Financial Markets and Institutions, 6(4), 7-11. doi:10.22495/rcgv6i4art1

Vasylieva, T., Harust, Yu., Vynnychenko, N., \& Vysochyna, A. (2018). Optimization of the financial decentralization level as an instrument for the country's innovative economic development regulation. Marketing and Management of Innovations, 4, 381- 390. http:/ / doi.org/10.21272/mmi.2018.4-33

World Bank. (2020). World development indicators 2017, World Bank. Retrieved from : https://data.worldbank.org/indicator

Yelnikova, Ju., Barhaq, A.R. (2020). Transparency of responsible investment environment. Business Ethics and Leadership, 4(4), 68-75. https://doi.org/10.21272/bel.4(4).68-75.2020

Zakharkina, L., Myroshnychenko, I., Smolennikov, D., \& Pokhylko, S. (2018). Efficiency of innovation activity funding as the driver of the state's national economic security. Montenegrin Journal of Economics, 14(4), 159-173. doi:10.14254/1800-5845/2018.14-4.11

Zaman, C., \& Drcelic, B. (2009). Macro-stabilisation issues in the Serbian Economy: Methodological Evaluation. Retrieved from http://ssrn.com/abstract $=1521660$.

Zandi, G., Torabi, R., \& Shamsudin, M. F. (2020). Trust, uncertainty and investment: An exploration of a hidden link. [Zaufanie, niepewność i inwestycja: Odkrycie ukrytej linii] Polish Journal of Management Studies, 22(2), 594-607. doi:10.17512/pjms.2020.22.2.39

Zolkover, A., \& Georgiev, M. (2020a). Shadow investment activity as a factor of macroeconomic instability. Financial Markets, Institutions and Risks, 4(4), 83-90. https://doi.org/10.21272/fmir.4(4).83-90.2020

Zolkover, A., \& Renkas, J. (2020b). Assessing the level of macroeconomic stability of EU Countries. SocioEconomic Challenges, 4(4), 175-182. https://doi.org/10.21272/sec.4(4).175-182.2020

Zolkover, A., \& Terziev, V. (2020c). The Shadow Economy: A Bibliometric Analysis. Business Ethics and Leadership, 4(3), 107-118. https://doi.org/10.21272/bel.4(3).107-118.2020 